DIGITAL COMMONS
@ UNIVERSITY OF SOUTH FLORIDA

Volume 11

Issue 1 Summer 2021

\section{ABO: Interactive Journal for \\ Women in the Arts, 1640-1830}

\title{
Forced Compartmentalization: Parenting, Professing, and Writing through the Age of COVID-19 and Anti-Asian Hate
}

\author{
Kathleen T. Alves \\ Queensborough Community Collete, City University of New York, kalves@qcc.cuny.edu
}

Follow this and additional works at: https://digitalcommons.usf.edu/abo

Part of the Arts and Humanities Commons, and the Educational Methods Commons

\section{Recommended Citation}

Alves, Kathleen T. (2021) "Forced Compartmentalization: Parenting, Professing, and Writing through the Age of COVID-19 and Anti-Asian Hate," ABO: Interactive Journal for Women in the Arts, 1640-1830: Vol.11: Iss. 1 , Article 10. http://doi.org/10.5038/2157-7129.11.1.1267

Available at: https://digitalcommons.usf.edu/abo/vol11/iss1/10

This Conversation is brought to you for free and open access by Digital Commons @ University of South Florida. It has been accepted for inclusion in ABO: Interactive Journal for Women in the Arts, 1640-1830 by an authorized administrator of Digital Commons @ University of South Florida. For more information, please contact digitalcommons@usf.edu. 
Forced Compartmentalization: Parenting, Professing, and Writing through the Age of COVID-19 and Anti-Asian Hate

\author{
Keywords \\ COVID-19, teaching, scholarship, parenting, sinophobia \\ Creative Commons License \\ (c) (1) (8)
}

This work is licensed under a Creative Commons Attribution-Noncommercial 4.0 License 
I initially worried that this piece would be another tired "make-lemonade-fromlemons" take on writing in the age of COVID-19, the kind of toxic optimism that nauseates me. I did manage to submit a chapter for publication in 2020, a feat that I am still reckoning with, given the intense physical, psychological, and emotional turbulence of that year.

Like many working mothers, I was suddenly tasked with teaching remotely and supporting my own children's remote schooling when New York state went into lockdown in March 2020. As an indefatigable planner who is used to unnecessarily juggling multiple balls since my undergraduate days, I drew up lists and schedules for myself and for my children so we can do all the things. I bought an hour-by-hour planner, which was a first for me, so I could block out times for meetings, grading blocks, meal prep, exercise. I scribbled the kids' schedules on a whiteboard and, in a desperate attempt to keep morale up, doodled a sad Spongebob exclaiming "You can do it!" It appeared to be fine. We are privileged to live in a sparsely populated town in Westchester, New York, far away from the epicenter of the pandemic in New York City. We are privileged that I can work from home, so we did not have to worry about childcare while my partner, a first responder in Manhattan, still had to commute to work. Other than my responsibilities to my family, my students, and my department, I said fuck that to everything else. I only had so much temporal, mental, and emotional bandwidth. I had neither ambition nor desire to get any writing done. The book manuscript I had been working on lay untouched, because honestly, what was the point? Who cares? I used my recent promotion to Associate Professor as a weak justification. I toiled ceaselessly for years so I can rest for a bit now, right? What better time to do that than in a pandemic?

Hunkered down in my home, I doomscrolled and virtually witnessed COVID-19 deaths and sickness, state-sanctioned and white supremacist violence. I witnessed in horror as people with my phenotype suffered from violent Sinophobia inflicted by racists emboldened by the administration's unapologetic scapegoating of Chinese people, a return to the Yellow Peril ethos from a century ago. I worried for myself and for my children, who looked more like me than their white father. I ran on autopilot with the gas gauge empty light on.

While teaching a summer course, I received an editor request inviting me to contribute a chapter to their collection, Critical Pedagogy: Teaching for Racial Inclusion in the Digital Age. At first, I was incredulous: Is this person for real? In a pandemic?! But as I sat on the invitation, I decided that this might be a good opportunity to think and write through some of the sticky, messy feelings about my experience teaching my students while the pandemic raged in Queens. 
Coincidentally, we were at the beginning of the course's unit on the history of Asian-American exclusion, Asian-American critique, and Celeste Ng's novel, Everything I Never Told You, and the material no longer felt theoretical or far removed from the present. My students, especially my Asian-American students, were living through similar politics of hate as the Asian workers on the transcontinental railroad in the nineteenth century and the novel's Asian characters in the novel set in 1970s Ohio. I submitted a proposal in early July, thinking that I could always inform the editor later that I would be unable to meet the December deadline, a month that seemed a century away.

That summer, I lived through two different realities. In the mornings, while my children played too many hours of video games, I immersed myself in racist histories and critique of the Asian-American's impossibility of national belonging. In the hot afternoons, I took my children on gorgeous hikes or dips in the neighborhood lake. We cultivated our gardens and kept a backyard birdwatching journal. I shielded my children from the news. It was as much for myself as it was for them, to saturate in beauty free from the presence of human beings. My misanthropy deepened, and I avoided social interaction in fear of possible infection and violence. This was our pandemic summer.

Though I withdrew from physical interaction in "the real world", I was buoyed by the emotional support from my \#WriteWithAphra writing group. The weekly virtual contact with other women, writing through similar parenting conditions in other parts of the world, motivated me to push through. I am indebted to them.

In the fall, I was offered the position as Deputy Chair. Energized by my anger at the relentless inequities in academia amplified by the pandemic, I advocated for BIPOC and women faculty to present their writing and research at our department symposium. I am also working with the two other Asian-American women faculty in my department, both early career scholars, for the April 2021 CUNY Diversity Conference, when we will present our experience teaching and researching through the age of COVID and anti-Asian hate. I have not seen my colleagues in person since March of 2020, but I like to imagine that our solidarity in teaching and thinking through COVID-19 has kept us afloat like a raft of ants trying not to drown in rough waters.

My children returned to their school with a hybrid schedule, allowing me to work incrementally on the promised piece. A century later, I met the December deadline, my pandemic primal scream packaged in an essay. It has been a year since lockdown and the violence against Asians has worsened, with the elderly 
bearing the brunt of unabated Sinophobia. My knuckles are still white while I continue to do the hard work of living. 